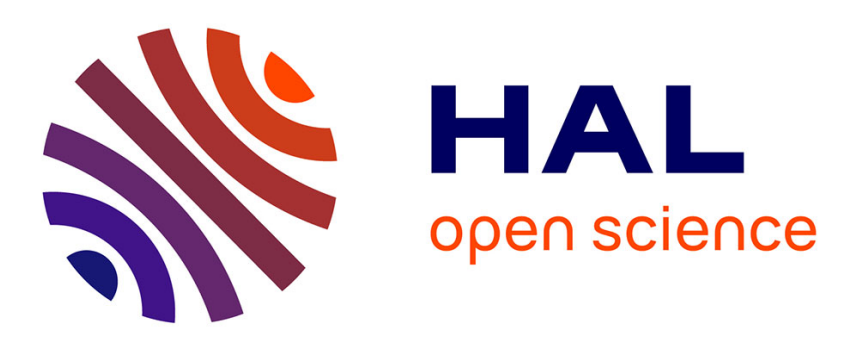

\title{
Fossil fuel biomarkers in sewage sludges: environmental significance
}

\author{
Cécile Payet, Carine Bryselbout, Jean-Louis Morel, Eric Lichtfouse
}

\section{To cite this version:}

Cécile Payet, Carine Bryselbout, Jean-Louis Morel, Eric Lichtfouse. Fossil fuel biomarkers in sewage sludges: environmental significance. Die Naturwissenschaften, 1999, 86 (10), pp.484-488. 10.1007/s001140050659 . hal-00262396

\section{HAL Id: hal-00262396 https://hal.science/hal-00262396}

Submitted on 11 Mar 2008

HAL is a multi-disciplinary open access archive for the deposit and dissemination of scientific research documents, whether they are published or not. The documents may come from teaching and research institutions in France or abroad, or from public or private research centers.
L'archive ouverte pluridisciplinaire HAL, est destinée au dépôt et à la diffusion de documents scientifiques de niveau recherche, publiés ou non, émanant des établissements d'enseignement et de recherche français ou étrangers, des laboratoires publics ou privés. 
Revised version

Naturwissenschaften 86, 484-488, 1999. doi: 10.1007/s001140050659

Correspondence: Dr. Eric Lichtfouse, INRA-CMSE-PME, 17, rue Sully, 21000 Dijon, France

Eric.Lichtfouse@dijon.inra.fr

\title{
Fossil fuel biomarkers in sewage sludges : environmental significance
}

\author{
Cécile PAYET, Carine BRYSELBOUT, Jean-Louis MOREL and Eric LICHTFOUSE* \\ Laboratoire Sols et Environnement, INRA-ENSAIA/INPL,
}

BP 172, 54505 Vandoeuvre-lès-Nancy, France

\begin{abstract}
Fossil fuel biomarkers, or "molecular fossils", are specific organic substances found in coals, petroleums and sedimentary rocks. They are formed during millions of years of sedimentary burial by geochemical alteration of biological molecules, e.g. cholesterol, under the effect of biodegradation, temperature, pressure and mineral catalysis, to produce geochemically mature molecules, e.g. aromatic steroids (Figure 1). Since fossil fuel biomarkers have a very specific molecular structure betraying fossil fuel sources, such markers should be useful to assess the fossil fuel contamination of various modern media such as soils, plants, waters and modern sediments. Here, the identification of fossil fuel biomarkers of high geothermal maturity in sewage sludges gives evidence for the contamination of sludges by petroleum products. The most likely sources of contamination are contaminated vegetal food, road dust, and soil particles carried by rain water.
\end{abstract}

\section{Introduction}

Urban sewage sludges are very complex media inherited from the decay of animal, vegetal, and rain wastes. About 850000 tons of dry weight sludges are yearly produced in France. Sludges can be usefully recycled in agriculture as fertilisers because they are enriched in NPKcompounds (Sommers, 1977, Parker and Sommers, 1983). Moreover, the introduction of these organic rich materials $(\sim 30 \% \mathrm{C})$ in crops could balance the lost of organic carbon observed during intensive cropping (Arrouays and Pelissier, 1994). Nonetheless, agricultural recycling is raising some concern because sludges contain small amounts of potentially toxic chemicals such as polychorinated biphenyls (PCBs), polychlorinated dibenzo- $p$-dioxins (PCDDs), polycyclic aromatic hydrocarbons (PAHs) and various volatile compounds which could be transferred to groundwater, plants, and atmosphere (Wilson and Jones, 1993, Wilson et al. 1994, 1997). In recent investigations we have shown the occurrence of traces of fuel biomarkers in soils and plants (Lichtfouse et al., 1997a, Bryselbout et al., 1998). Here we report the identification of several classes of typical fossil fuel biomarkers (Volkman et al., 1992) such as pristane, phytane, tricyclic terpane, steranes, diasteranes and hopanes in sewage sludges from Nancy, France. Calculation of their geochemical maturities demonstrates the input of a highly mature fossil fuel source such as petroleum products carried by aerosol dust.

* author to whom all correspondence should be addressed 


\section{Fossil fuel biomarkers}

Fossil fuel biomarkers, also called 'molecular fossils' are organic substances mainly found in sediments, petroleum and coal (Albrecht and Ourisson, 1971). They are formed during millions of years of sedimentary burial by alteration of biological precursors under the effect of biodegradation, temperature, and mineral catalysis (Mackenzie et al., 1982). As a fish bone fossil reveals the presence of a fish species millions of years ago, the preservation of the steroid skeleton of fossil aromatic steroids betray the occurrence of a sterol precursor (Figure 1). The structural changes undergone by molecular fossils during burial have been widely use to understand the mechanisms ruling the fate of sedimentary organic matter. For instance, parameters based on stereochemical changes of molecular fossils are useful tools to measure the thermal maturity of fossil organic matter in sediments and petroleums (Mackenzie et al., 1982, Lichtfouse et al., 1994). Furthermore, since fossil fuels ultimately re-enter modern ecosystems, one can expect to find molecular fossils in modern media. Indeed, several investigations report the use of such molecular tools to assess the occurrence of petroleum contamination (Dastillung and Albrecht, 1976, Albaigés and Albrecht, 1979, Hostettler et al., 1989, 1992, Volkman et al., 1992, Aboul-Kassim and Simoneit, 1995, Moldowan et al., 1995, Lichtfouse et al., 1997a, Bryselbout et al., 1998) . Recently, we have identified traces of fossil fuel hopanes in soils (Lichtfouse et al., 1997a) and in cuticular waxes of plant species growing near a highway (Bryselbout et al., 1998). Since these fuel products most likely come from the aerosol deposition, e.g. of vehicle exhausts (Lichtfouse et al., 1997b), we suspected that they should be further harvested by rainfall and ultimately end in urban sewage sludges.

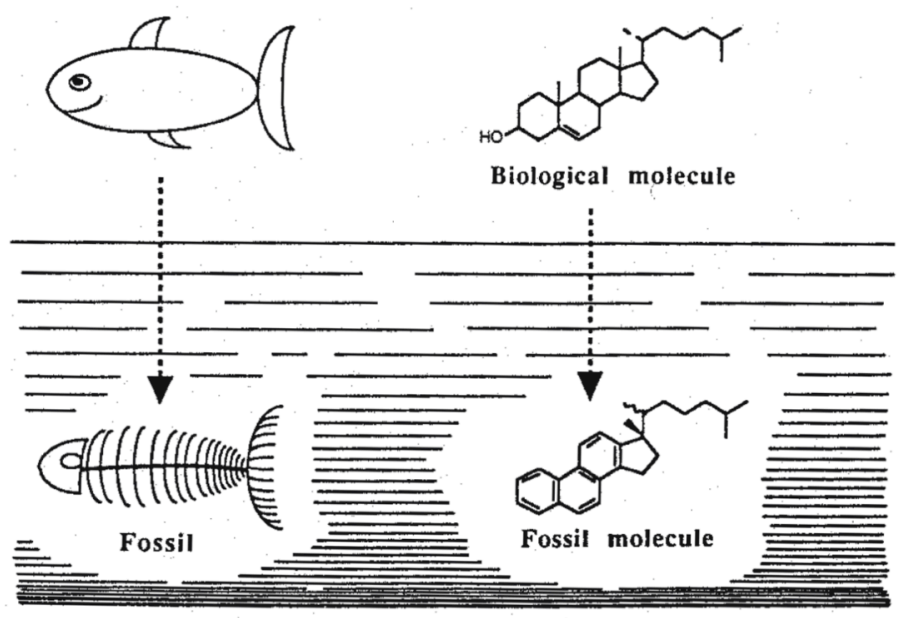

Figure 1. Molecular fossils are formed during millions of years of sedimentary burial by degradation of biological substances. The preservation of specific steroid skeletons allows to correlate fossil aromatic steroids with biological sterols.

\section{Sludge analysis}

Six biological sludges were sampled at two storage facilities in the Nancy area. Sludges have been previously anaerobically digested then dewatered by centrifugation. $\mathrm{The} \mathrm{CH}_{2} \mathrm{Cl}_{2}$ extracts of the sludges were fractionated by silica gel thin layer chromatography into alkane, aromatic, ketone, alcohol and polar fractions as described elsewhere (Payet et al., 1999). The alkane fractions were analysed by gas chromatography coupled to mass spectrometry. The molecular structures of the substances identified are drawn on Figure 2. A typical total ion current of alkane 
fractions is given on Figure 3. It shows the occurrence of various substances of modern and ancient origin. A major peak of elemental sulfide elutes between $\mathrm{C}_{20}$ and $\mathrm{C}_{21} n$-alkanes. This presence of sulfide fits well with the anaerobic conditions of the sludges. Indeed, sulfide is produced in various anaerobic environments by sulfate-reducing bacteria (Jørgensen, 1983). A such finding indicates that sulfide may be used as a redox marker in further studies of sewage application on soils.
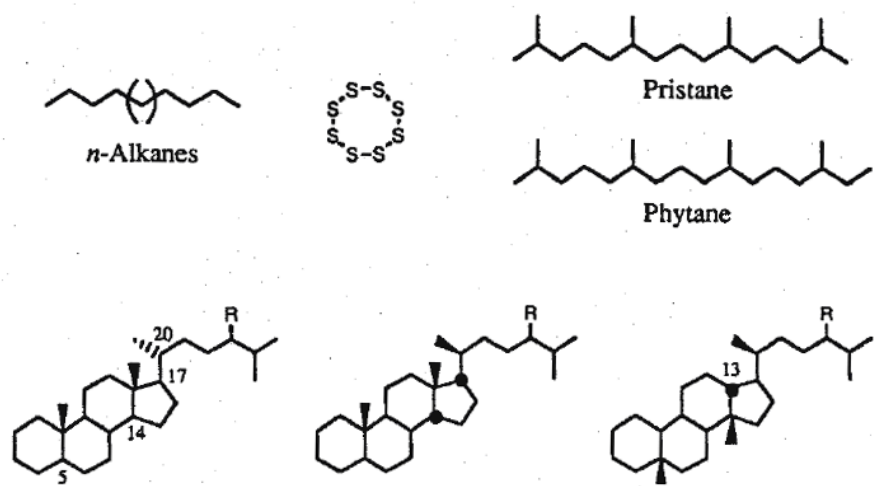

$5 \alpha, 14 \alpha, 17 \alpha 20 \mathrm{R}$ Steranes (" $\left.\alpha \alpha R^{\prime}\right)$ $\mathrm{R}=\mathrm{H}, \mathrm{CH}_{3}, \mathrm{C}_{2} \mathrm{H}_{5}$

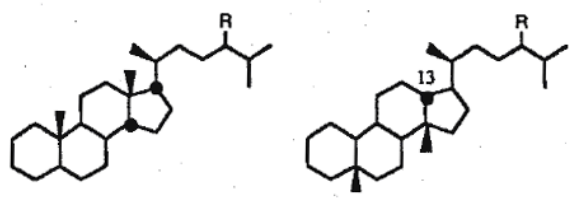

$5 \alpha, 14 \beta, 17 \beta 20 \mathrm{~S}$ Steranes (" $\beta \beta S$ ")

$14 \beta, 17 \alpha 20 S$ Diasteranes (" $\beta \alpha S ")$

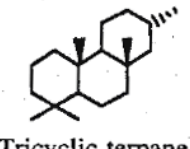

Tricyclic terpane $\left(\mathrm{C}_{19}\right)$

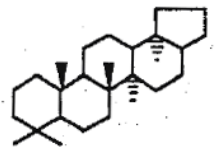

$\operatorname{Tm}\left(\mathrm{C}_{27}\right)$

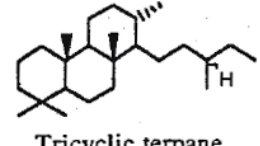

$\left(\mathrm{C}_{25}\right)$

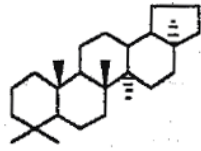

Ts $\left(C_{27}\right)$

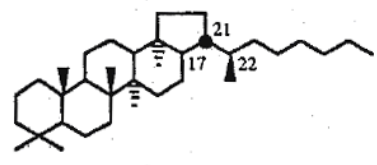

$17 \alpha, 21 \beta, 22 R-H o p a n e\left(C_{35}\right)$

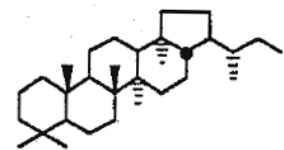

$17 \beta, 21 \alpha, 22 \mathrm{~S}$-Hopane $\left(\mathrm{C}_{31}\right)$

Figure 2. Substances identified in the alkane fraction of a urban sewage sludge $\mathrm{CH}_{2} \mathrm{Cl}_{2}$ extract. Tm : 17 $\alpha$-22,29,30trisnorneohopane, Ts : $18 \alpha-22,29,30$-trisnorneohopane. $\beta \alpha$-hopanes and trycyclic terpanes are also named "moretane" and "cheilanthanes", respectively.

\section{Linear alkanes}

Linear alkanes extend from $\mathrm{C}_{13}$ to $\mathrm{C}_{33}$ (Figure 3). They can be classified into two categories according to their source. First, short-chain $n$-alkanes extending from $\mathrm{C}_{13}$ to $\mathrm{C}_{24}$ are derived from fossil fuel sources. The ancient origin of these substances is evidenced by calculation of the carbon preference index (CPI), a parameter widely used in petroleum geochemistry to measure odd/even carbon preference (Tissot and Welte, 1984). Sludges give an average CPI value of 1.2. This absence of odd/even predominance is typical of organic matter which has been subjected to thermal stress through geological times, e.g. petroleum and coal (Tissot and Welte, 1984). Moreover, similar fingerprints have been observed in contaminated soils and in diesel (Lichtfouse et al., 1997b, Lichtfouse et Eglinton, 1995). Therefore, the presence of ancient alkanes in sewage sludge strongly suggests the input of a fossil fuel source. This finding is in good agreement with 
the occurrence of fossil fuel pollution in plants and soils (Lichtfouse et Eglinton, 1995, Lichtfouse et al., 1997a,b, Bryselbout et al., 1998) since sludges are partly made of digested vegetal matter and of rain washings of various surfaces such as soils and roads.

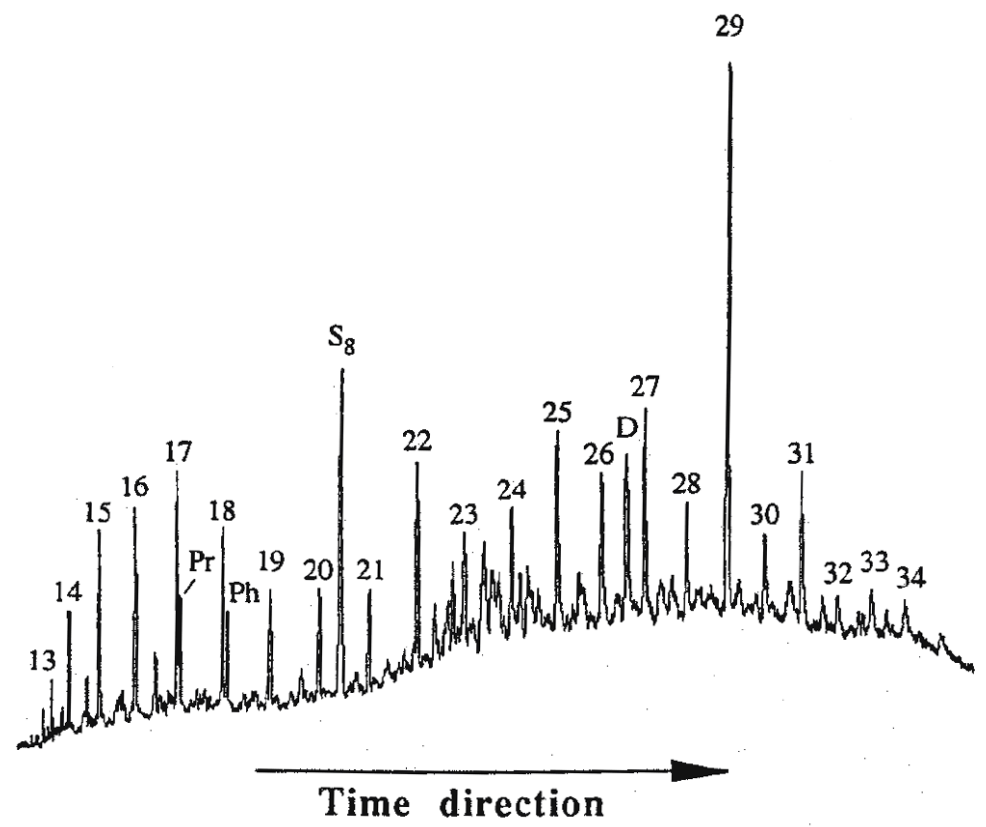

Figure 3. Total ion current of an alkane fraction from sewage sludges, showing petroleum products (13-24, $\mathrm{Pr}, \mathrm{Ph}$, $D)$, sulfide $\left(S_{8}\right)$, and plant wax n-alkanes (25-33). Numbers refer to carbon numbers of linear alkanes. Pr : pristane, $\mathrm{Ph}$ : phytane, $\mathrm{D}: \beta \alpha \mathrm{S}$-diacholestane and an unknown substance. Alkane fractions were analysed with a Varian Star 3400 gas chromatograph coupled to a Saturn 2000 ion trap mass spectrometer. Conditions: helium pressure 8 psi; on column injector; $28 \mathrm{~m} \mathrm{x} 0.25 \mathrm{~mm}$ i.d. fused silica gel column coated with 5\%phenyl-, 95\% methylpolysiloxane phase $\left(0.25 \mu \mathrm{m}\right.$ thickness); oven temperature : $30^{\circ} \mathrm{C}$ isothermal $1 \mathrm{~min}, 30-150^{\circ} \mathrm{C}$ at $15.6^{\circ} / \mathrm{min}, 150-310^{\circ} \mathrm{C}$ at $3 \% \mathrm{~min}$ then $310^{\circ} \mathrm{C}$ isothermal $30 \mathrm{~min}$; $\mathrm{EI} 70 \mathrm{eV}$, scan 40-650 amu, solvent delay $6 \mathrm{~min}$. Carbon preference indexes (CPI) were calculated using peak heights as follows : CPI short-chain $\left(\mathrm{C}_{15}+\mathrm{C}_{17}+\mathrm{C}_{19}\right) /\left(\mathrm{C}_{18}+\mathrm{C}_{20}+\mathrm{C}_{24}\right)$; CPI long-chain $\left(\mathrm{C}_{27}+\right.$ $\left.\mathrm{C}_{29}+\mathrm{C}_{31}\right) /\left(\mathrm{C}_{26}+\mathrm{C}_{28}+\mathrm{C}_{30}\right)$.

Second, long-chain $n$-alkanes extending from $\mathrm{C}_{25}$ to $\mathrm{C}_{33}$ show a strong odd carbon-number predominance with an average CPI value of 2.8. This strong even predominance is typical of $n$-alkanes found in plant cuticular waxes (Eglinton and Hamilton, 1967, Bryselbout et al., 1998, Lichtfouse et al., 1998) and in low-contaminated soils (Lichtfouse et Eglinton, 1995, Lichtfouse et al., 1997b). Therefore, the occurrence of odd-predominant long-chain $n$-alkanes in sludges indicates the input of modern plant. Such $n$-alkanes could originate from vegetal food because $n$ alkanes are more resistant to biodegradation relatively to sugars and amino acids. Thus, they should have partly gone through human digestion without alteration, and then end in sludges. Alternatively, soil erosion by rain should have led to the transfer of plant-derived soil $n$-alkanes into sludges.

\section{Pristane and phytane}

Pristane $\left(\mathrm{C}_{19}\right)$ and phytane $\left(\mathrm{C}_{20}\right)$ elute just after $\mathrm{C}_{17^{-}}$and $\mathrm{C}_{18} n$-alkanes, respectively (Figure 3). Pristane and phytane are typically found in thermally mature organic matter such as petroleum and sedimentary rocks (Tissot and Welte, 1984). These substances are formed at the time of sedimentary deposition by degradation of the phytyl side-chain of chlorophyll. It has been postulated that phytol degradation leads to the preferential formation of phytane versus pristane 
under anaerobic sedimentary conditions. Thus, the pristane/phytane ratios can been applied to evaluate the redox palaeoconditions. Here, sludge $\mathrm{Pr} / \mathrm{Ph}$ values of $\sim 1,2$ indicate that the fossil fuel pollution had been formed during geological times by deposition of a sediment under rather aerobic water column conditions, e.g. ocean or open sea. A such information may help to track the precise origin of the sewage pollution. Whatever origin, the occurrence of pristane and phytane in sludges points again to the contamination of sewage sludges by a fossil fuel source.

\section{Steranes and diasteranes}

The main steranes and diasteranes extend from $\mathrm{C}_{27}$ to $\mathrm{C}_{29}$ (Figure 2). The fossil fuel origin of these substances is evidenced by several features. In sedimentary rocks, sterane derivatives are formed by degradation of biological sterols $(\alpha \alpha \mathrm{R})$ leading to the predominance of sterenes in shallow sediments, then steranes at intermediate depths, then diasteranes in deep formations and in petroleums (Mackenzie et al., 1980, 1982, Lichtfouse and Rullkötter, 1994, Lichtfouse et al., 1994). During sedimentary burial, the geologically mature $\beta \beta S$-sterane isomers replace gradually the immature $\alpha \alpha \mathrm{R}$-sterane isomers (Mackenzie et al., 1980, 1982). Analyses of sludge steranes shows the predominance of geothermally mature isomers such as $\beta \beta S$-steranes and diasteranes. Moreover, calculation of maturity parameters based on sterane isomers gives high average values, e.g. $52 \%$ for $\alpha \alpha S$ - versus $\alpha \alpha \mathrm{R}$-cholestane and $60 \%$ for $\beta \alpha \mathrm{S}$-diacholestane versus $\alpha \alpha \mathrm{S}$ cholestane. Such high values are only found in petroleums and in deep sedimentary rocks (Mackenzie et al., 1980, Lichtfouse et al., 1994). Furthermore, since diasteranes are formed by clay-catalysed rearrangement of sterenes in sedimentary rocks (Sieskind et al., 1979, Sieskind and Albrecht, 1985), their occurrence in sludges indicates that the fossil fuel pollution had been formed in a clay-rich palaeoenvironnement. As a consequence, a possible input from coal particles is unlikely, making petroleum contamination such as vehicle exhausts a more favourable source.

\section{Tricyclic terpanes}

Sewage sludges contain tricyclic terpanes extending from $\mathrm{C}_{19}$ to $\mathrm{C}_{26}$ as shown on the reconstructed ion current at $\mathrm{m} / \mathrm{z} 191$ (Figure 4). These molecular fossils have been identified in biodegraded petroleums and asphalts (Aquino Neto et al., 1982, Ekweozor and Strausz, 1982, Moldowan et al., 1983, Ekweozor, 1984). So far, their biological precursors are still unknown (Ourisson et al., 1982, 1987). Whatever biological origin, their occurrence in sludges confirm the input of fossil matter, rather petroleum- than coal-derived. 


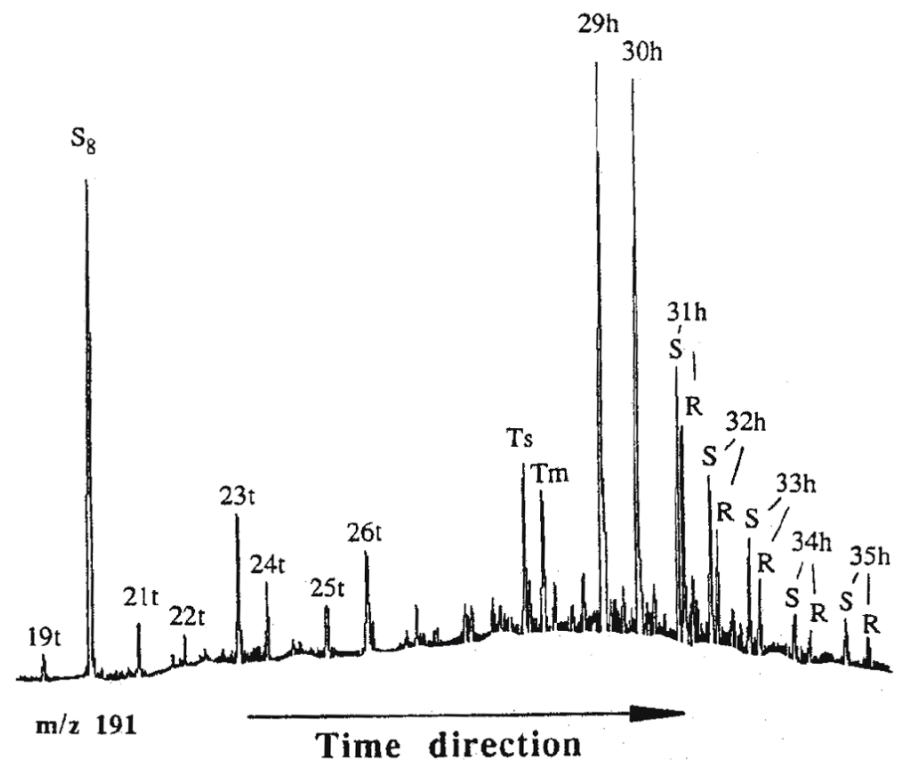

Figure 4. Reconstructed ion current at m/z 191 of an alkane fraction from sewage sludges, showing petroleumderived tricyclic terpanes (19t-26t) and hopanes (Ts, Tm, 29h-35h). Hopanes bear the geothermally mature $17 \alpha, 21 \beta$ configuration (Lichtfouse and Rullkötter, 1994).

\section{Hopanes}

Sewage sludges contain hopane derivatives extending from $\mathrm{C}_{27}$ to $\mathrm{C}_{35}$ as shown on the reconstructed ion current at m/z 191 (Figure 4). Hopanes found in sedimentary rocks are formed by diagenesis of bacterial hopanols (Ourisson et Albrecht, 1992). During sedimentary burial, the geologically mature $\alpha \beta S$-hopane isomers replace gradually the immature $\beta \beta \mathrm{R}$ isomers (Lichtfouse and Rullkötter, 1994). Thus, the hopane fingerprint of sludges is typical of highly mature fossil fuels, as evidenced by the predominance of the geologically mature $\alpha \beta S$ configuration versus the immature $\beta \beta \mathrm{R}$ configuration (undetected here). Geological maturity parameters such as $\mathrm{C}_{31}-\alpha \beta \mathrm{S} / \mathrm{R}(56 \%)$ and $\mathrm{Ts} / \mathrm{Tm}(54 \%)$ give average values typical of organic matter which has undergone a high thermal stress during geological times (Seifert and Moldowan, 1978). Therefore, the occurrence of mature hopanes in sludges clearly confirms the input of a fossil fuel contamination. Moreover, similar maturity values have been observed in soils and in plants contaminated by trace levels of fossil fuels (Lichtfouse et al., 1997a, Bryselbout et al., 1998). This result thus strengthens the possible transfer of soil and plant contamination to sewage sludges.

\section{Conclusion}

Short-chain $n$-alkanes, pristane, phytane, steranes, diasteranes, tricyclic terpanes, and hopane derivatives typical of ancient, geothermally mature organic matter have been identified in sewage sludges. These findings give evidence for the contamination of sludges by petroleum products. The most likely sources of contamination are contaminated vegetal food, road dust, and soil particles carried by rain waters. Further work is in progress to try to understand the mechanisms governing pollutant transfer in these modern ecosystems. 


\section{REFERENCES}

Aboul-Kassim TAT, Simoneit BRT (1995) Petroleum hydrocarbon fingerprinting and sediment transport assessed by molecular biomarker and multivariate statistical analyses in the eastern harbour of Alexandria, Egypt. Marine Pollut Bull 30:63-73

Albaigés J, Albrecht P (1979) Fingerprinting marine pollutant hydrocarbons by computerized gas chromatography-mass spectrometry. Intern J Environ Anal Chem 6:171-190

Albrecht P, Ourisson G (1971) Biogenic substances in sediments and fossils. Angew Chem Internat Edit 10:209-225

Aquino Neto FR, Restle A, Connan J, Albrecht P, Ourisson G (1982) Novel tricyclic terpanes $\left(\mathrm{C}_{19}, \mathrm{C}_{20}\right)$ in sediments and petroleums. Tetrahedron Lett 23:2027-2030

Arrouays D, Pelissier P (1994) Changes in carbon storage in temperate humic loamy soils after forest clearing and continuous corn cropping in France. Plant Soil 160:215-223

Bryselbout C, Henner P, Lichtfouse E (1998) Fossil fuel biomarkers in plant waxes as pollution parameters. Sci Tot Environ 222:201-204

Dastillung M, Albrecht P (1976) Molecular test for oil pollution in surface sediments. Marine Pollut Bull 7:13-15

Eglinton G, Hamilton RJ (1967) Leaf epicuticular waxes. Science 156:1322-1335

Ekweozor CM (1984) Tricyclic terpenoid derivatives from chemical degradation reactions of asphaltenes. Org Geochem 6:51-61

Ekweozor CM, Strausz OP (1982) 18,19-Bisnor-13 $\beta H, 14 \alpha H$-cheilanthane: a novel degraded tricyclic sesterterpenoid-type hydrocarbon from Athabasca oil sands. Tetrahedron Lett 23, 27112714

Hostettler FD, Rapp JB, Kvenvolden KA (1992) Use of geochemical biomarkers in bottom sediment to track oil from a spill, San Francisco Bay, California. Marine Pollut Bull 24:15-20 Hostettler FD, Rapp JB, Kvenvolden KA, Luoma SN (1989) Organic markers as source discriminants and sediment transport indicators in south San Francisco Bay, California. Geochim Cosmochim Acta 53:1563-1576

Jørgensen BB (1983) The microbial sulfur cycle. In: Krumbein WE (ed) Microbial Geochemistry. Blackwell, pp 91-124

Lichtfouse E, Albrecht P, Behar F, Hayes JM (1994) A molecular and isotopic study of the organic matter from the Paris Basin, France. Geochim Cosmochim Acta 58:209-221

Lichtfouse E, Bardoux G, Mariotti A, Balesdent J, Ballentine DC, Macko SA (1997b) Molecular, ${ }^{13} \mathrm{C}$, and ${ }^{14} \mathrm{C}$ evidence for the allochthonous and ancient origin of $\mathrm{C}_{16}-\mathrm{C}_{18} n$-alkanes in modern soils. Geochim Cosmochim Acta 61:1891-1898

Lichtfouse E, Budzinski H, Garrigues Ph, Eglinton TI (1997a) Ancient polycyclic aromatic hydrocarbons in modern soils : ${ }^{13} \mathrm{C},{ }^{14} \mathrm{C}$ and biomarker evidence. Org Geochem 26:353-359 Lichtfouse, E, Eglinton TI (1995) ${ }^{13} \mathrm{C}$ and ${ }^{14} \mathrm{C}$ evidence of pollution of a soil by fossil fuel and reconstruction of the composition of the polluant. Org Geochem 23:969-973

Lichtfouse E, Rullkötter J. (1994) Accelerated transformation of organic matter below the silica transition zone in immature sediments from the Japan Sea. Org Geochem 21, 517-523.

Lichtfouse E, Wehrung P, Albrecht P (1998) Plant wax $n$-alkanes trapped in soil humin by noncovalent bonds. Naturwissenschaften 85:449-452

Mackenzie AS, Brassell SC, Eglinton G, Maxwell JR (1982) Chemical fossils: the geological fate of steroids. Science 217:491-509

Mackenzie AS, Patience RL, Maxwell JR, Vandenbroucke M, Durand B (1980) Molecular parameters of maturation in the Toarcian shales, Paris Basin, France. I. Changes in the 
configurations of acyclic isoprenoid alkanes, steranes and triterpanes. Geochim Cosmochim Acta 44:1709-1721

Moldowan JM, Dahl J, McCaffrey MA, Smith WJ, Fetzer JC (1995) Application of biological marker technology to bioremediation of refinery by-products. Energy Fuels 9:155-162

Moldowan JM, Seifert WK, Gallegos EJ (1983) Identification of an extended series of tricyclic terpanes in petroleum. Geochim Cosmochim Acta 47:1531-1534

Ourisson G, Albrecht P (1992) Hopanoids. 1. Geohopanoids: the most abundant natural products on Earth? Acc Chem Res 25:398-402

Ourisson G, Albrecht P, Rohmer M (1982) Predictive microbial biochemistry - from molecular fossils to procaryotic membranes. TIBS 236-239

Ourisson G, Rohmer M, Poralla K (1987) Microbial lipids betrayed by their fossils. Microbiol Sci 4:52-57

Parker CF, Sommers LE (1983) Mineralization of nitrogen in sewage sludges. J Environ Qual 12:150-156

Payet C, Bryselbout C, Morel JL, Lichtfouse E (1999) Organic Geochemistry of Sewage Sludge. I. Lipid Fractionation by Thin Layer Chromatography. Analusis, in press.

Seifert WK, Moldowan JM (1978) Applications of steranes, terpanes and monoaromatics to the maturation, migration and source of crude oils. Geochim Cosmochim Acta 42:77-95

Sieskind O, Albrecht P (1985) Efficient synthesis of rearranged cholest-13(17)-enes catalysed by montmorillonite-clay. Tetrahedron Lett 26:2135-2136

Sieskind O, Joly G, Albrecht P (1979) Simulation of the geochemical transformations of sterols: superacid effect of clay minerals. Geochim Cosmochim Acta 43:1675-1679

Sommers LE (1977) Chemical composition of sewage sludges and analysis of their potential use as fertilizers. J Environmental Qual 6:225-232

Tissot BP, Welte DH (1984) Petroleum Formation and Occurrence. Springer, Berlin Volkman JK, Holdsworth DG, Neill GP, Bavor Jr HJ (1992) Identification of natural, anthropogenic and petroleum hydrocarbons in aquatic sediments. Sci Tot Environ 112:203-219 Wilson SC, Alcock AP, Sewart AP, Jones KC (1997) Persistence of organic contaminants in sewage sludge-amended soil: a field experiment. J Environ Qual 26:1467-1477

Wilson SC, Burnett V, Waterhouse KS, Jones KC (1994) Volatile organic compounds in digested United Kingdom sewage sludges. Environ Sci Technol 28:259-266

Wilson SC, Jones KC (1993) Bioremediation of soil contaminated with polynuclear aromatic hydrocarbons (PAHs): a review. Environ Pollut 81:229-249 